\title{
Amyloid Fibril Toxicity Still Unresolved
}

\author{
Kimberly L. Clapp-Lilly \\ and Lawrence K. Duffy \\ Institute of Arctic Biology and Department of \\ Chemistry and Biochemistry, University of \\ Alaska Fairbanks, Fairbanks, Alaska 99775, \\ USA
}

In this issue of Journal of Alzheimer's Disease, Yatin et al. (1) show that presence of the predominant form of $A \beta$ deposited in senile plaques of $\mathrm{AD}$ brain, full-length $\mathrm{A} \beta(1-42)$, induces markers of oxidative stress including protein carbonyl formation, ROS production and membrane lipid peroxidation and that the endogenous antioxidant vitamin $\mathrm{E}$ attenuates this oxidative stress. However, Yatin et al. also demonstrate qualitatively that vitamin $\mathrm{E}$ does not prevent $A \beta(1-42)$ fibril formation in contradiction to the current hypothesis that the amyloid in its fibril form is not only the source of, but also necessary for free radical production in AD (2). Over the last ten years, fibril formation and protein aggregation have been associated with many neurodegenerative disorders including Alzheimer's disease (AD) (3-5). Amyloid- $\beta(A \beta)$ is the major proteinaceous constituent of senile (neuritic) plaques found in $\mathrm{AD}$ brain. $\mathrm{A} \beta(25-35)$ and $A \beta(1-40)$ peptides have previously been shown to induce oxidative stress in neuronal culture $(2,6,7)$ and to be inextricably linked using an in vivo transgenic mouse model $(8,10)$.

$\mathrm{A} \beta(1-42)$ is deposited early and selectively in senile plaques of $\mathrm{AD}$ patients suggesting that it is a major determinant of AD pathology (9). Missense mutations, developed in transgenic mouse models of $\mathrm{AD}$, that lead to amino acid substitu- tions at residue 717 in $\beta$ PP produce high levels of larger $A \beta$ species (10). Also, in studies of early onset cases of $\mathrm{AD}$, mutations in the presenilin genes result in higher levels of $A \beta(1-42)$ (11). Exposure of neurons in culture to $A \beta(1-42)$ has shown the formation of calcium-permeable membrane channels which can disrupt intracellular ion homeostasis (12-14). Changes in ion homeostasis can lead to the induction of oxidative stress by free radical production. The increase in free radical levels can be either generated by amyloid peptides and fibrils or, conversely, lead to an increase in the stability of amyloid fibrils in neuritic plaques.

$\mathrm{A} \beta(1-42)$ is produced in the endoplasmic reticulum by recently characterized $\gamma$-secretase which cleaves the amyloid precursor protein. Many $A \beta$ peptide fragments generate beta-sheets but $A \beta(1-42)$, possibly due to the two extra hydrophobic amino acids on its carboxyl terminus $(15,16)$, forms the $\beta$-sheet structure more readily. $A \beta(1-42)$, therefore, becomes more insoluble than the shorter A $\beta$ peptides (17). Soto and colleagues hypothesize that the initiation of betasheet conformation is thermodynamically unfavorable in all $A \beta$ and that an intermediate step between the random coil/ $\alpha$-helix and beta-sheet state may exist (17). Metal ions (such as aluminum and zinc) and $\mathrm{pH}$ changes (possibly caused by reactive oxygen species) may stabilize this uncharacterized intermediate as well as nucleate the production of more beta-sheet fibrils (18-21), supporting the hypothesis that AD pathology involving $A \beta$ and metal ions depends on the fibril formation. On the other hand, methionine in $A \beta$ may be a major contributor to the generation of free radicals without a requirement for a specific fibril type. If the latter is correct, then the 
amount of free radical formation should not be correlated with the quantity of fibrils.

Berlett and Stadtman (22) have pointed out the generality that the accumulation of oxidized protein (protein carbonyls) is associated with not only AD but with many other neurodegenerative diseases including progenia and Werner's syndrome. Yatin et al.'s (1) demonstration of a reduction in oxidative damage as well as a reduction in cell death by the addition of vitamin $\mathrm{E}$ suggests that fibril formation might not be a cause of oxidative damage but an associated effect. In this $J A D$ paper, Yatin et al. (1) have taken an important first step in resolving the role of fibrils in the mechanism of amyloid toxicity. However, until a quantitative evaluation of the number of fibrils can be correlated with free radical production or oxidative damage, an uncertainty about the role of fibrils in AD will remain.

The acknowledgment of our lack of understanding of the exact mechanism of amyloidosis is very important when considering alternative therapies. For example, one therapeutic approach to $\mathrm{AD}$ has been the development of small "betabreaker" peptides (peptides involving proline residues), capable of disrupting and/or preventing the $A \beta$ beta-sheet conformation by stabilizing the random coil/ $\alpha$-helix conformation (17). However, if the exact mechanism is not known, this should not be the only avenue pursued. Also, these peptides must be exogenously injected into brain and thus, it would be advantageous to find endogenous molecules that not only inhibit $A \beta$ aggregation but also reduce free radicals, no matter what their original source. Since aggregation may involve oxidative stress, it may be likely that some natural or synthetic antioxidants could prevent amyloid formation and oxidative stress while others such as vitamin E do not and thus only act as radical scavengers.

Studies have shown that the endogenous antioxidants melatonin and estrogen prevent fibrillogensis $(23,24)$. How these antioxidants inhibit fibril formation has not been determined but it is likely that they bind to sites on amyloid peptide monomers, preventing interactions necessary for fibril formation. Melatonin has also been reported to scavenge free radicals and cross the blood brain barrier (25).

The discovery by Yatin et al. (1) in this issue of $J A D$ that vitamin $\mathrm{E}$ cannot inhibit $\mathrm{A} \beta$ fibril formation may indicate that the structure of the fibril is not as important as the free radical scavenging capability of the antioxidant. Because this paper casts doubt on previous assumptions, it is an important finding in the search for a mechanism of $\mathrm{A} \beta$ toxicity. Once the mechanism is clearly identified, therapeutic approaches to $\mathrm{AD}$ should directly follow. Lastly, as Berlett and Stadtman (22) point out, since ROS formation is involved in many other diseases, a successful therapy for $\mathrm{AD}$ will have an impact on neurodegeneration in general.

\section{REFERENCES}

1. Yatin SM, Varadarajan S, Butterfield DA, Vitamin E prevents Alzheimer's amyloid $\beta$-peptide (1-42)-induced neuronal protein oxidation, reactive oxygen species production and cell death, but does not inhibit fibril formation, Journal of Alzheimer's Disease 2(2) 123-131.

2. Behl C, Davis JB, Lesley R, Schubert D, Hydrogen peroxide mediates amyloid $\beta$ protein toxicity, Cell 77 (1994) 817-827.

3. Masliah E, Rockenstein D, Veinbergs I, Mallory M, Hashimoto M, Takeda A, Sagara Y, Sisk A, Mucke L, Dopaminergic loss and inclusion body formation in $\alpha$-synuclein mice: implications for neurodegenerative disorders, Science 287 (2000) 1265-1269.

4. Kaytor MD, Warren ST, Aberrant protein deposition and neurological disease, J Biol Chem 274 (1999) 37507-37510.

5. Yankner BA, Mechanisms of neuronal degeneration in Alzheimer's disease, Neuron 16 (1996) 921-932.

6. Butterfield DA, Hensley K, Harris M, Mattson M, Carney JM, $\beta$-Amyloid peptide free radical fragments initiate synaptosomal lipoperoxidation in a sequence-specific fashion: implications to Alzheimer's disease, Biochem Biohys Res Commun 200 (1994) 710-715.

7. Pereira C, Santos MS, Oliveira C, Involvement of oxidative stress on the impairment of energy metabolism induced by A $\beta$ peptides on PC12 cells: protection by antioxidants, Neurobiology of Dis- 
ease 6 (1999) 209-219.

8. Smith MA, Hirai K, Hsiao K, Pappolla MA, Harris PLR, Siedlak SL, Tabaton M, Perry G, Amyloid- $\beta$ deposition in Alzheimer transgenic mice is associated with oxidative stress, J Neurochem 70 (1998) 2212-2215.

9. Younkin SG, The role of $\mathrm{A} \beta(1-42)$ in Alzheimer's disease, J Physiol Paris 92 (1998) 289292.

10. Hsiao K, Chapman P, Nilsen S, Eckman C, Harigaya $\mathrm{Y}$, Correlative memory deficits, $\mathrm{A} \beta$ elevation and amyloid plaques in transgenic mice, Science 274 (1996) 99-102.

11. Scheuner D, Eckman C, Jensen M, Song X, Citron M, Suzuki N, Bird TD, Hardy J, Hutton M, Kukull W, Larson E, Levy-Lahad E, Viitanen M, Peskind E, Poorkaj P, Schellenberg G, Tanzi R, Wasco W, Lannfelt L, Selkoe D, Younkin S, Secreted amyloid $\beta$-protein similar to that in the senile plaques of Alzheimer's disease is increased in vivo by the presenilin 1 and 2 and APP mutations linked to familial Alzheimer's disease, Nature Medicine 2 (1996) 864-870.

12. Rhee SK, Quist AP, Lal R, Amyloid $\beta$ protein-(142) forms calcium-permeable $\mathrm{Zn}^{2+}$-sensitive channel, J Biol Chem 273 (1998) 13379-13382.

13. Koo EH, Squazzo SL, Selkoe DJ, Koo CH, Trafficking of cell-surface amyloid $\beta$-protein precursor 1 . Secretion, endocytosis and recycling as detected by labeled monoclonal antibody, J Cell Sci 109 (1996) 991-998.

14. Fraser PE, Duffy LK, O’Malley MB, Nguyen J, Inouye H, Kirschner DA, Morphology and antibody recognition of synthetic beta-amyloid peptides, J Neurosci Res 28 (1991) 474-485.

15. Hilbich C, Kisters-Woike B, Reed J, Master CL, Beyreuther K, Substitutions of hydrophobic amino acids reduce the amyloidogenicity of Alzheimer's disease $\beta \mathrm{A} 4$ peptides, J Mol Biol 288 (1992) 460-473.
16. Soto C, Castano EM, The conformation of Alzheimer's $\beta$ peptide determines the rate of amyloid formation and its resistance to proteolysis, Biochem J 314 (1996) 701-707.

17. Soto C, Castano EM, Frangione B, Inestrosa NC, The alpha-helical to beta-strand transition in the amino-terminal fragment of the amyloid betapeptide modulates amyloid formation, $\mathbf{J}$ Biol Chem 270 (1995) 3063-3067.

18. Wisniewski T, Ghiso J, Frangione B, Alzheimer's disease and soluble $A \beta$, Neurobiol Aging 15 (1994) 143-152.

19. Teplow DB, Structural and kinetic features of amyloid beta-protein fibrillogenesis, Amyloid 5 (1998) 121-142.

20. Barrow CJ, Yasuda A, Kenny PT, Zagorski MG, Solution conformations and aggregational properties of synthetic amyloid beta-peptides of Alzheimer's disease. Analysis of circular dichroism spectra, J Mol Biol 225 (1992) 1075-1093.

21. Vyas SB, Duffy LK, Interaction of synthetic Alzheimer $\beta$-protein derived analogs with aqueous aluminum: A low field 27AL NMR investigation, Journal of Protein Chemistry 14 (1995) 633-644.

22. Berlett BS, Stadtman ER, Protein oxidation in aging, disease and oxidative stress, J Biol Chem 272 (1997) 20313-20314.

23. Pappolla M, Bozner P, Soto C, Shao H, Robakis NK, Zagorski M, Frangione B, Ghiso J, Inhibition of Alzheimer $\beta$-fibrillogenesis by melatonin, $\mathrm{J}$ Biol Chem 273 (1998) 7185-7188.

24. Mook-Jung I, Joo I, Sohn S, Kwon HJ, Huh K, Jung MW, Estrogen blocks neurotoxic effects of beta-amyloid (1-42) and induces neurite extension in B103 cells, Neurosci Lett 235 (1997) 101-104.

25. Reiter RJ, The pineal gland and melatonin in relation to aging: a summary of the theories and of the data [Review], Exp Gerontology 30 (1995) 199-212. 